\title{
THERMAL-MECHANICAL BEHAVIOR OF COMPACTED GMZ BENTONITE
}

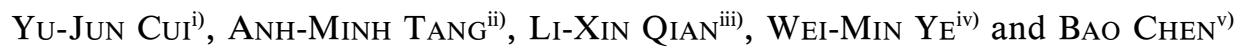

\begin{abstract}
The THM behavior of compacted GMZ bentonite has been investigated using a suction-temperature controlled isotropic cell. The results obtained were compared with the existing results on other reference bentonites (MX80, FEBEX, FoCa, and Kunigel-V1). It has been observed that the coefficient of thermal expansion of the compacted GMZ bentonite is $2 \times 10^{-4} \mathrm{C}^{-1}$, similar to the values of compacted MX80 and FEBEX bentonites. The heating tests of the GMZ bentonite also show that the suction is an important parameter that governs the thermal volumetric behavior of unsaturated soils. Unlike temperature, suction has a significant effect on the compressibility parameters. Examination of the mineralogy of various bentonites showed that a good correlation can be generally established between the montmorillonite content and the cations exchange capacity (CEC) or the specific surface area (S). Nevertheless, both the basic geotechnical properties and the swelling potential seem to depend not only on the montmorillonite content but also on other factors such as the nature of base exchangeable cations. The quartz content of the GMZ bentonite is relatively high $(11.7 \%)$. This could explain its relatively large values of thermal conductivity.
\end{abstract}

Key words: compacted GMZ bentonite, comparison, high-level radioactive waste disposals, suction, temperature, thermo-mechanical behavior (IGC: D5/D8)

\section{INTRODUCTION}

Considering the key role played by the engineered barrier systems (EBS) in deep radioactive waste disposals, notably related to i) isolation functions, ii) containment functions, and iii) retrievability, compacted bentonites are often considered the best candidates for engineered barrier materials. As an assessment of the EBS performance under complex thermo-hydro-mechanical (THM) loadings is crucial in demonstrating the long-term safety of disposal systems, large investigations are generally needed for a selected bentonite. The experiments in these investigations must cover various scales, from small-scale elementary laboratory tests through to mid-scale to largescale tests in underground research facilities. Various reference bentonites have been studied in various countries for this purpose: Kunigel-V1 is used as the reference material for all the clay-based components in the repository concepts in Japan (Sugita et al., 2007); MX80 was used in the Swedish prototype repository project (Johannesson et al., 2007); the FoCa clay from the Paris Basin and the Serrata clay from Spain which is equally known as the FEBEX bentonite (Lloret and Villar, 2007) were considered in the RESEAL project performed in Belgium (Van Geet et al., 2007).
The preliminary long-term plan for the implementation of China's high-level radioactive waste repository (Wang et al., 2006) suggests that a high-level radioactive waste repository will be built in the middle of the 21 st Century. In the Chinese concept of geological disposal, bentonite has been selected as the buffer/backfill material. The Gaomiaozi (GMZ) Na-bentonite taken from a large-scale deposit located in the North Chinese Inner Mongolia $\mathrm{Au}$ tonomous Region (300 km northwest of Beijing) has been chosen for this purpose. After Wen (2006), preliminary research conducted on the swelling, mechanical, hydraulic, and thermal properties have shown that the GMZ bentonite is a good buffer/backfill material. Indeed, as reported by Wen (2006), it has relatively high thermal conductivity $(K=1.51 \mathrm{~W} / \mathrm{mK}$ at a dry density of 1.6 $\mathrm{Mg} / \mathrm{m}^{3}$ and a water content of $26.7 \%$ ), quite low water permeability (at saturated state, $k=1.94 \times 10^{-13} \mathrm{~m} / \mathrm{s}$ at a dry density of $1.6 \mathrm{Mg} / \mathrm{m}^{3}$ and a temperature of $25^{\circ} \mathrm{C}$ ), a relatively high unconfined compression strength $(1.74$ $\mathrm{MPa}$ at a dry density of $1.6 \mathrm{Mg} / \mathrm{m}^{3}$ and a water content of $23.6 \%$ ), and quite a high swelling pressure (3.17 MPa at a dry density of $1.6 \mathrm{Mg} / \mathrm{m}^{3}$ ). Chen et al. (2006) completed the experimental investigation by determining the water retention curves of the GMZ bentonite and showed its high retention capacity which is necessary for ensuring

\footnotetext{
Professor, Tongji University, China, and Ecole des Ponts ParisTech, U.R. Navier/CERMES, France (yujun.cui@enpc.fr).

Researcher, Ecole des Ponts ParisTech, U.R. Navier/CERMES, France.

PhD, Tongji University, China.

Professor, Tongji University, China.

Associate Professor, Tongji University, China.

The manuscript for this paper was received for review on September 28, 2010; approved on June $27,2011$.

Written discussions on this paper should be submitted before July 1, 2012 to the Japanese Geotechnical Society, 4-38-2, Sengoku, Bunkyo-ku, Tokyo 112-0011, Japan. Upon request the closing date may be extended one month.
} 
the containment function of the EBS.

Though sufficient preliminary experimental data have been obtained, allowing the candidature of the GMZ bentonite to be retained, there is still a great need of experimental data needed in terms of THM coupling behavior in order to confirm this candidature. In this regard, there have been some results allowing a relevant analysis. In one study, Ye et al. (2009) determined the unsaturated hydraulic conductivity of the GMZ bentonite under constant volume conditions and they observed a strong coupling between water flux and mechanical confining: the hydraulic conductivity determined was found first to decrease and then increase with decreasing suction. The decrease can be attributed to the large pore clogging due to soft gel creation by the exfoliation process. This coupling phenomenon was also observed on a mixture of the Kunigel-V1/Hostun sand (Cui et al., 2008). In the present work, a complementary study was performed to further investigate the coupled thermo-mechanical behavior of the GMZ bentonite. The suction-temperature controlled isotropic cell developed by Tang et al. (2007) was used for this purpose. The results obtained cover the swelling upon wetting, the volumetric changes upon heating, and the compressibility at controlled suction and temperature. Furthermore, the properties found for GMZ bentonite in this investigation were compared with those of other reference bentonites available in the literature.

\section{MATERIALS AND METHODS}

\section{Materials}

Table 1 presents the mineralogical properties of the GMZ bentonite, as well as other reference bentonites: the Kunigel-V1, FoCa, MX80 and FEBEX. These bentonites contain mainly montmorillonite, which is an essential mineral to ensure sealing properties. Beside the montmorillonite, there is quartz, which is also an important mineral for its particular influence on thermal conductivity (Tang et al., 2008b). Note that a high thermal conductivity of the engineered barrier allows the heat to dissipate quickly from the canisters, consequently reducing the maximum temperature in the EBS. This is one of the reasons why sand/bentonite mixtures are equally studied as buffer material in the repository concepts of Canada (Martino et al., 2007) and Japan (Sugita et al., 2007).

The physical properties of GMZ bentonite are presented in Table 2. Compared to other bentonites, GMZ bentonite has high montmorillonite content, which gives it a high Cations Exchange Capacity $(\mathrm{CEC}=77.30 \mathrm{meq} / 100$ $\mathrm{g})$, a large plasticity index $\left(I_{\mathrm{p}}=275\right)$, and a large specific surface area $\left(S=570 \mathrm{~m}^{2} / \mathrm{g}\right)$. Note also that the main base cations are $\mathrm{Na}$ and $\mathrm{Ca}$.

\section{Methods}

As mentioned previously, the present work aims at investigating the thermo-mechanical behavior of the GMZ bentonite. For the samples preparation, soil powder with an initial water content of $12.2 \%$ was firstly compacted in
Table 1. Mineral composition of some bentonites

\begin{tabular}{lccccc}
\hline \multicolumn{1}{c}{ Mineral } & $\begin{array}{c}\mathrm{Kunigel}_{\mathrm{V}}^{\mathrm{a}} \\
\mathrm{V}\end{array}$ & $\mathrm{FoCa}^{\mathrm{b}}$ & $\mathrm{MX80}$ & $\mathrm{FEBEX}^{\mathrm{d}}$ & $\mathrm{GMZ}^{\mathrm{e}}$ \\
\hline $\begin{array}{l}\text { Montmorillonite } \\
\text { (\%) }\end{array}$ & $46-49$ & $\begin{array}{c}80 \% \\
\text { (interstratified } \\
\text { smectite/ } \\
\text { kaolinite) }\end{array}$ & 79 & $92 \pm 3$ & 75.4 \\
Plagioclase (\%) & - & - & 9.2 & $2 \pm 1$ & - \\
Pyrite (\%) & $0.5-0.7$ & - & $0 .-$ & $0.02 \pm 0.01$ & - \\
Calcite (\%) & $2.1-2.6$ & 1.4 & 0.8 & Traces & 0.5 \\
Dolomite (\%) & $2.0-2.8$ & - & - & $0.60 \pm 0.13$ & - \\
Gypsum (\%) & - & 0.4 & - & $0.14 \pm 0.01$ & - \\
Halite (\%) & - & - & - & $0.13 \pm 0.02$ & - \\
Analcite (\%) & $3.0-3.5$ & - & - & - & - \\
Mica (\%) & - & - & $<1$ & - & - \\
Feldspar (\%) & $2.7-5.5$ & - & 2.0 & Traces & 4.3 \\
Cristobalite (\%) & - & - & - & $2 \pm 1$ & 7.3 \\
Kaolinite (\%) & - & 4 & - & - & 0.8 \\
Quartz (\%) & $29-38$ & 6 & 2.8 & $2 \pm 1$ & 11.7 \\
Field organic & $0.31-0.34$ & - & 0.1 & $0.35 \pm 0.05$ & - \\
\hline
\end{tabular}

${ }^{a}$ JNC (2000); ${ }^{b}$ Guillot et al. (2002); ${ }^{\circ}$ Montes-H. et al.(2003); ${ }^{\mathrm{d}}$ ENRESA (2000); ${ }^{\mathrm{e}} \mathrm{Wen}(2006)$.

Table 2. Physical properties of some bentonites

\begin{tabular}{lccccc}
\hline \multicolumn{1}{c}{ Parameter } & Kunigel-V1 $^{\mathrm{a}}$ & FoCa $^{\mathrm{b}}$ & $\mathrm{MX}^{\mathrm{c}} 0^{\mathrm{c}}$ & FEBEX $^{\mathrm{d}}$ & $\mathrm{GMZ}^{\mathrm{e}}$ \\
\hline Particle $<2 \mu \mathrm{m}(\%)$ & 64.5 & - & 60 & 68 & 60 \\
CEC (meq $/ 100 \mathrm{~g})$ & 73.2 & 54 & 82.3 & $102^{\mathrm{j}}$ & 77.30 \\
Base cations & $\mathrm{Na}-\mathrm{Ca}$ & $\mathrm{Ca}$ & $\mathrm{Na}$ & $\mathrm{Ca}-\mathrm{Mg}$ & $\mathrm{Na}-\mathrm{Ca}$ \\
Exchange & 474 & 112 & 519 & 102 & 313 \\
$w_{\mathrm{L}}(\%)$ & 27 & 50 & 35 & 53 & 38 \\
$w_{\mathrm{P}}(\%)$ & 447 & 62 & 484 & 49 & 275 \\
$I_{\mathrm{P}}$ & 2.79 & 2.67 & 2.76 & 2.70 & 2.66 \\
$\rho_{\mathrm{s}}\left(\mathrm{Mg} / \mathrm{m}^{3}\right)$ & 687 & 300 & 522 & 725 & 570 \\
$S\left(\mathrm{~m}^{2} / \mathrm{g}\right)$ & & & &
\end{tabular}

${ }^{\mathrm{a}}$ Komine (2004); ${ }^{\mathrm{b}}$ Marcial et al. (2002); ${ }^{\mathrm{c}}$ Tang and Cui (2005); ${ }^{\mathrm{d}}$ ENRESA (2000); ${ }^{\mathrm{e}} \mathrm{Wen}$ (2006).

an isotropic cell under a static pressure of $30 \mathrm{MPa}$. The dry density after compaction was about $1.70 \mathrm{Mg} / \mathrm{m}^{3}$. The compacted sample was then cut and machined to obtain smaller samples of size $80 \mathrm{~mm}$ diameter and $10 \mathrm{~mm}$ high. All the samples were then put in a sealed box with a relative humidity controlled by a saturated solution of $\mathrm{K}_{2} \mathrm{CO}_{3}$ for about one week ( see technical details in Delage et al., 1998). That permitted an initial suction of $110 \mathrm{MPa}$ to be imposed on the samples. The soil volume changes during this suction initialization have been found to be negligible. That is in agreement with the water retention curve obtained by Chen et al. (2006), showing a suction of about $110 \mathrm{MPa}$ at a water content of about $12 \%$ for a sample compacted to a dry density of $1.70 \mathrm{Mg} / \mathrm{m}^{3}$.

The isotropic cell developed by Tang et al. (2007), which enables the study of mechanical properties of compacted expansive soils using simultaneous control of suction and temperature, was used in the present work. The basic scheme of the cell is presented in Fig. 1. The soil specimen ( $80 \mathrm{~mm}$ in diameter and $10 \mathrm{~mm}$ high) was sandwiched between two dry porous stones, both of which were embedded in metallic plates. Small holes $(2 \mathrm{~mm}$ diameter) were drilled in the lower plate, allowing the 


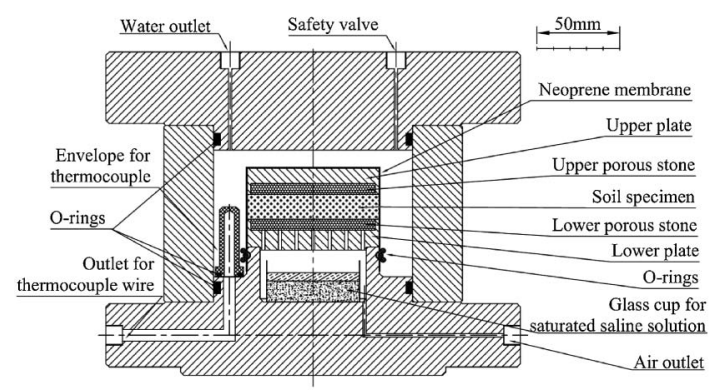

Fig. 1. Basic scheme of the suction-temperature controlled isotropic cell (after Tang et al., 2007)

moisture exchange between the soil specimen and chamber below the lower plate. A glass cup containing an oversaturated saline solution was placed in the chamber to control the soil suction. A neoprene membrane $(1.2 \mathrm{~mm}$ thick) covered the soil specimen and the two metallic plates, avoiding any exchange between the confining water in the cell and the soil pore water. A thermocouple installed inside the cell was used to monitor the cell temperature, which was considered equal to the temperature of the soil specimen during the test. The cell was immersed in a temperature-controlled bath within a temperature fluctuation of $\pm 0.1{ }^{\circ} \mathrm{C}$. A volume/pressure controller was used to apply the confining pressure in the cell. This volume/pressure controller was also used to monitor the volume change of the soil specimen through the volume change of the confining water in the cell. During the test, volume and pressure readings of the volume/ pressure controller as well as the cell temperature were recorded by a computer.

Following the tests carried out by Tang et al. (2008a) on compacted MX80 bentonite, thermal loadings were applied over a short duration of less than $24 \mathrm{~h}$, and the soil suction was assumed to remain unchanged within this short time. The soil suction was then equal to the total suction imposed by the saturated salt solution. Tang and Cui (2005) measured the suctions generated by saturated salt solutions at different temperatures, and these results were applied in this investigation to determine the imposed suction at a given temperature. The saturated salt solution, which filled the glass cup of the cell, was chosen according to the desired values of suction and temperature during the test. Three suctions were considered: 9 $\mathrm{MPa}\left(\mathrm{KNO}_{3}\right.$ at $25^{\circ} \mathrm{C}$ and $\mathrm{K}_{2} \mathrm{SO}_{4}$ at $\left.60^{\circ} \mathrm{C}\right) ; 39 \mathrm{MPa}(\mathrm{NaCl}$ at $25^{\circ} \mathrm{C}$ and $\left.60^{\circ} \mathrm{C}\right)$; and $110 \mathrm{MPa}\left(\mathrm{K}_{2} \mathrm{CO}_{3}\right.$ at $25^{\circ} \mathrm{C}$, $\mathrm{MgNO}_{3}$ at $60^{\circ} \mathrm{C}$ ).

For tests at suctions lower than the initial suction of $110 \mathrm{MPa}$, the total suction was initially imposed outside the cell by putting the samples in a sealed box containing saturated $\mathrm{KNO}_{3}$ solution (9 $\mathrm{MPa}$ suction) or $\mathrm{NaCl}$ solution (39 MPa suction). The soil sample volume change due to this suction decrease was monitored using a precision caliper. The mass of the soil sample was determined every 3 days until it reached a stable value. The sample was installed inside the isotropic cell only after this suction equilibrium process. Prior to the test, the dimensions
Table 3. Stress paths of thermo-mechanical tests

\begin{tabular}{llrrrrrr}
\hline & & T1 & T2 & T3 & T4 & T5 & T6 \\
\hline \multirow{3}{*}{ Initial } & $p: \mathrm{MPa}$ & 0 & 0 & 0 & 0 & 0 & 0 \\
condition & $s: \mathrm{MPa}$ & 110 & 110 & 110 & 110 & 110 & 110 \\
& $T:{ }^{\circ} \mathrm{C}$ & 25 & 25 & 25 & 25 & 25 & 25 \\
\hline \multirow{5}{*}{ Path I } & $p: \mathrm{MPa}$ & 0.1 & 0 & 0 & 0 & 0 & 0 \\
& $s: \mathrm{MPa}$ & 110 & 39 & 9 & 110 & 39 & 9 \\
& $T:{ }^{\circ} \mathrm{C}$ & 25 & 25 & 25 & 25 & 25 & 25 \\
\hline \multirow{5}{*}{ Path II } & $p: \mathrm{MPa}$ & 50 & 0.1 & 0.1 & 0.1 & 0.1 & 0.1 \\
& $s: \mathrm{MPa}$ & 110 & 39 & 9 & 110 & 39 & 9 \\
& $T:{ }^{\circ} \mathrm{C}$ & 25 & 25 & 25 & 25 & 25 & 25 \\
\hline \multirow{5}{*}{ Path III } & $p: \mathrm{MPa}$ & & 50 & 50 & 0.1 & 0.1 & 0.1 \\
& $s: \mathrm{MPa}$ & & 39 & 9 & 110 & 39 & 9 \\
& $T:{ }^{\circ} \mathrm{C}$ & & 25 & 25 & 60 & 60 & 60 \\
\hline \multirow{3}{*}{ Path IV } & $p: \mathrm{MPa}$ & & & & 50 & 30 & 30 \\
& $s: \mathrm{MPa}$ & & & & 110 & 39 & 9 \\
& $T:{ }^{\circ} \mathrm{C}$ & & & & 60 & 60 & 60 \\
\hline
\end{tabular}

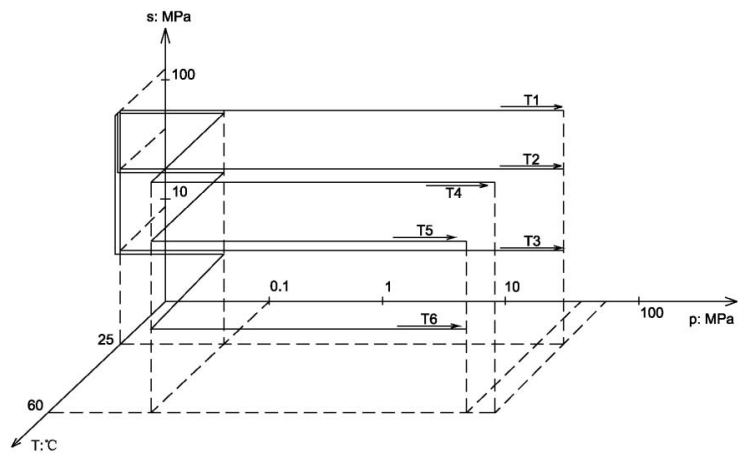

Fig. 2. Stress paths of tests T1-T6

of the sample were adjusted to fit the required size ( 80 $\mathrm{mm}$ in diameter and $10 \mathrm{~mm}$ high).

A total of six tests were performed (T1 to T6) and their stress paths are presented in Table 3 and Fig. 2, in a space of total suction $(s)$, pressure $(p)$ and temperature $(T)$. During a mechanical compression test the cell pressure was increased in steps from 0.1 to $0.2,0.5,1,2,5,10,20$ and $50 \mathrm{MPa}$. The volume change of water in the volume/ pressure controller was recorded for each step. Calibration tests at various temperatures and pressures were performed with a metallic specimen that had the same dimensions as the soil specimen. An example of the determination of soil volume change for a loading step from 1 to $2 \mathrm{MPa}$ (test T1) is shown in Fig. 3. The deformation of the metallic specimen was assumed to be negligible within this range of pressure (lower than $50 \mathrm{MPa}$ ) and the water volume change recorded during the calibration corresponds mainly to the deformation of the cell and the tubing. The volume change of the soil sample was then deduced from the difference between the calibration curve and the curve from test, as depicted in Fig. 3. This volume change was used to calculate the volumetric strain of the soil sample upon mechanical loading.

Figure 4 shows the determination of the soil volume 


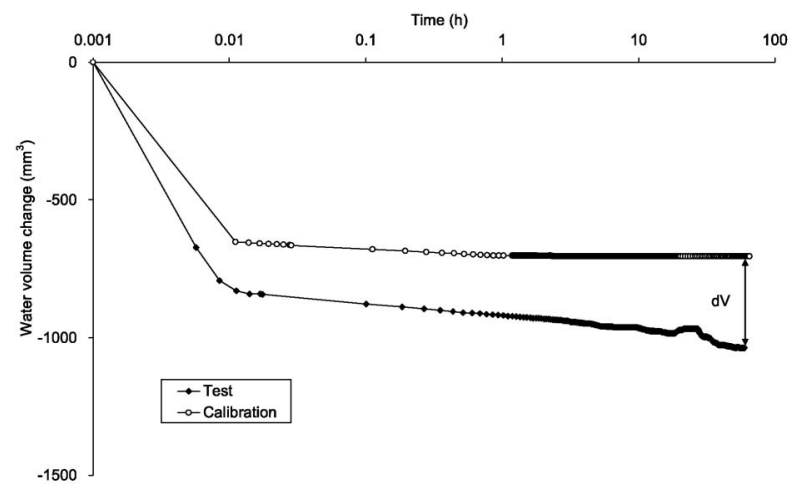

Fig. 3. Determination of soil volume change during loading step from 1 to $2 \mathrm{MPa}$

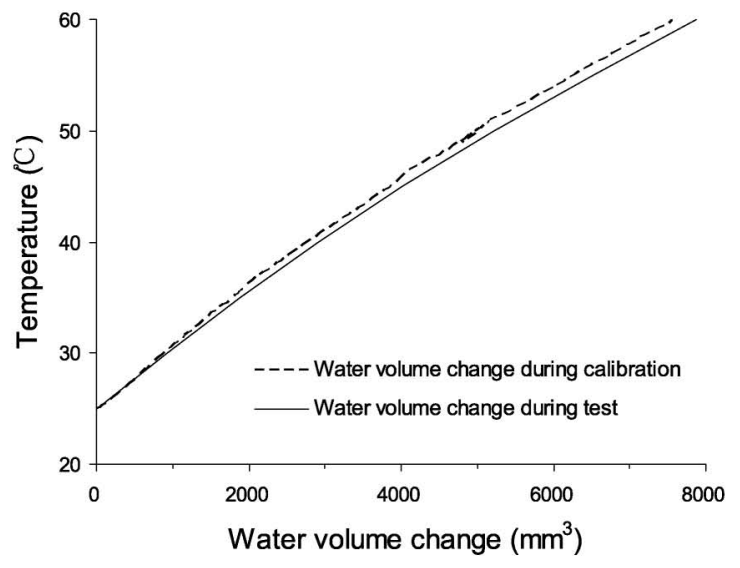

(a)

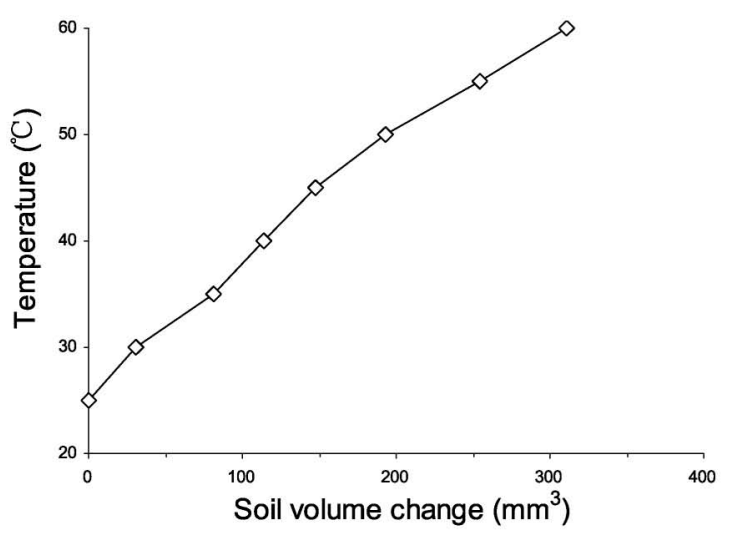

(b)

Fig. 4. Determination of soil volume change during heating under confining pressure of $0.1 \mathrm{MPa}$

change during heating from $25^{\circ} \mathrm{C}$ to $60^{\circ} \mathrm{C}$ under a constant pressure of $0.1 \mathrm{MPa}$ (test T4). Upon heating, the water in the cell expanded and moved into the volume/ pressure controller. According to Romero et al. (2005), the thermal expansion coefficient of compacted expansive soil is approximately $10^{-4 \circ} \mathrm{C}^{-1}$, much higher than the metal specimen $\left(10^{-60} \mathrm{C}^{-1}\right)$ used for the calibration.

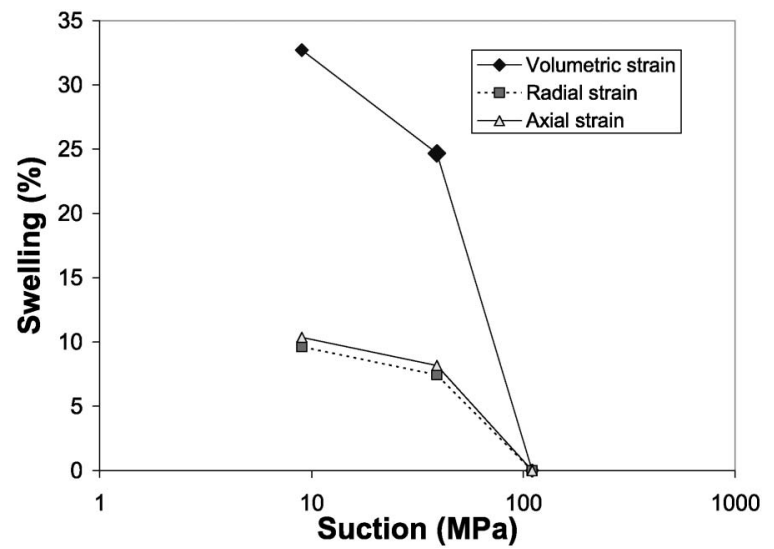

Fig. 5. Axial, radial and volumetric strain during wetting

Thus, it can be reasonably assumed that the thermal expansion of the metal was negligible in comparison with that of the soil. The soil volume change during heating can be then determined from the difference between two curves obtained during the calibration and the test (Fig. 4a). In the case of test $\mathrm{T} 4$ while heating from 25 to $60^{\circ} \mathrm{C}$, the soil volume increased by $310 \mathrm{~mm}^{3}$ (Fig. 4b), which corresponds to a volumetric strain $\varepsilon_{\mathrm{v}}$ of $-0.622 \%$.

\section{EXPERIMENTAL RESULTS}

\section{Soil Volume Change during the Initial Humidification}

Figure 5 shows a typical result of volumetric strain of the soil specimens due to wetting from the initial suction $(110 \mathrm{MPa})$ to 39 and $9 \mathrm{MPa}$, as well as axial and radial strains. It can be seen that the radial strain is almost equal to the axial strain, showing isotropic behavior in the soil specimen. This observation is consistent with the procedure of compaction under isotropic pressure adopted for the specimen preparation. A similar observation was also made by Tang et al. (2008a). Furthermore, it can be noticed that the total volume of the soil specimen is increased by $32.9 \%$ when the suction is decreased to $9 \mathrm{MPa}$ from $110 \mathrm{MPa}$.

\section{Volume Change under Thermal Loading}

As shown in Fig. 2, the initial state was defined by zero pressure, $25^{\circ} \mathrm{C}$ temperature and $110 \mathrm{MPa}$ suction. For test $\mathrm{T} 4$, the soil specimen in its initial state was confined to a pressure $p=0.1 \mathrm{MPa}$, and heated to a temperature $T$ $=60^{\circ} \mathrm{C}$ under $p=0.1 \mathrm{MPa}$. For test $\mathrm{T} 5$, a decrease of suction from 110 to $39 \mathrm{MPa}$ at $T=25^{\circ} \mathrm{C}$ was first undertaken during the initial wetting before the application of the confining pressure $p=0.1 \mathrm{MPa}$; heating to $T=60^{\circ} \mathrm{C}$ then followed. For test T6, the soil specimen was wetted to a suction of $9 \mathrm{MPa}$ and then loaded to $p=0.1 \mathrm{MPa}$ and heated to $T=60^{\circ} \mathrm{C}$.

Figure 6 shows the results for the thermal volume change under $p=0.1 \mathrm{MPa}$. The results from tests T4 (110 $\mathrm{MPa})$ and T5 (39 MPa) show that heating induces expansion and the coefficients of thermal expansion is $\alpha=2 \times$ $10^{-4 \circ} \mathrm{C}^{-1}$. On the contrary, the result from test T6 (9 


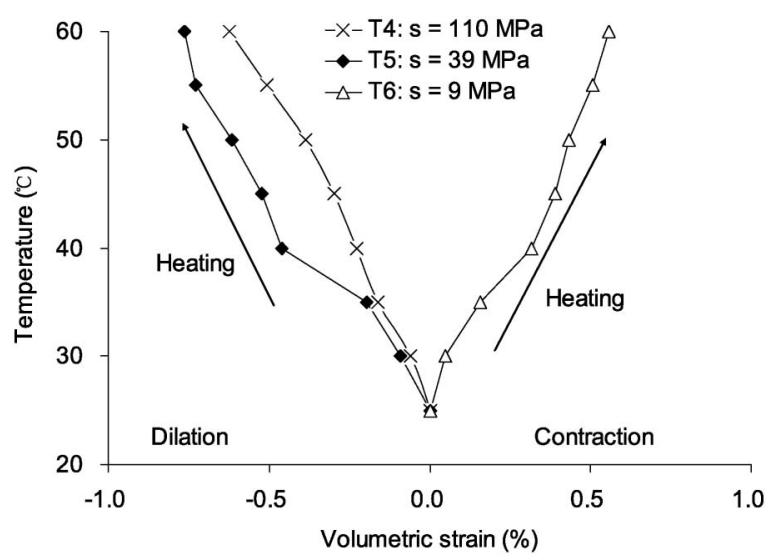

Fig. 6. Volumetric strain during thermal loading under constant pressure at 0.1 MPa: tests T4-T6

$\mathrm{MPa}$ ) shows a volume decrease upon heating.

\section{Volume Change under Mechanical Loading}

As shown in Fig. 2, the mechanical loadings in tests T1-T5 were performed at constant suction and temperature. Two temperatures $\left(25\right.$ and $\left.60^{\circ} \mathrm{C}\right)$ and three suctions $(110,39$ and $9 \mathrm{MPa})$ were applied. The results (the void ratio $e$ against the $\operatorname{logarithm}$ of pressure $\log p$ ) for all these tests are presented in Fig. 7. The compressibility parameters, such as the yield pressure $p_{0}$, defined as the pressure at the intersection between the two quasi-linear segments, the elastic compressibility parameter, $\kappa$, which is related to the slope of small changes in the void ratio, and the plastic compressibility parameter, $\lambda(s)$, which is related to the slope of large changes in void ratio, can be determined from these curves. It is to be noted that the notations defined by Alonso et al. (1990) are adopted here for the compressibility parameters.

From Fig. 7(a) it can be observed that temperature increase from $25^{\circ} \mathrm{C}$ to $60^{\circ} \mathrm{C}$ raises the void ratio from 0.508 to 0.518 at a pressure of $0.1 \mathrm{MPa}$ and constant suction of $110 \mathrm{MPa}$. This indicates thermal expansion due to heating at low pressure which is consistent with the results shown in Fig. 6. The effect of heating on volume change is much smaller than the volume change under subsequent mechanical loading. This phenomenon can be observed again at constant suction of $39 \mathrm{MPa}$, as depicted in Fig. 7(b). Heating from $25^{\circ} \mathrm{C}$ to $60^{\circ} \mathrm{C}$ slightly increased the void ratio $e$ from 0.754 to 0.768 . Again, the volume change due to heating is small compared to that due to subsequent mechanical loading. When comparing the compression curves of $\mathrm{T} 2\left(25^{\circ} \mathrm{C}\right)$ and $\mathrm{T} 5\left(60^{\circ} \mathrm{C}\right)$, it is observed that the difference is not significant. Moreover, the shape of the compression curve is similar to that obtained for T1 and T4. At $9 \mathrm{MPa}$ suction, only one loading test was performed (T3); a technical problem occurred during test $\mathrm{T} 6$. The compression curve for test $\mathrm{T} 3$ is presented in Fig. 7(c).

Though the temperature effects on $\lambda(s)$ and $\kappa$ are found to be negligible, this is not the case for the suction effect. Indeed, Fig. 8 shows that $\lambda(s)$ and $\kappa$ increase significantly

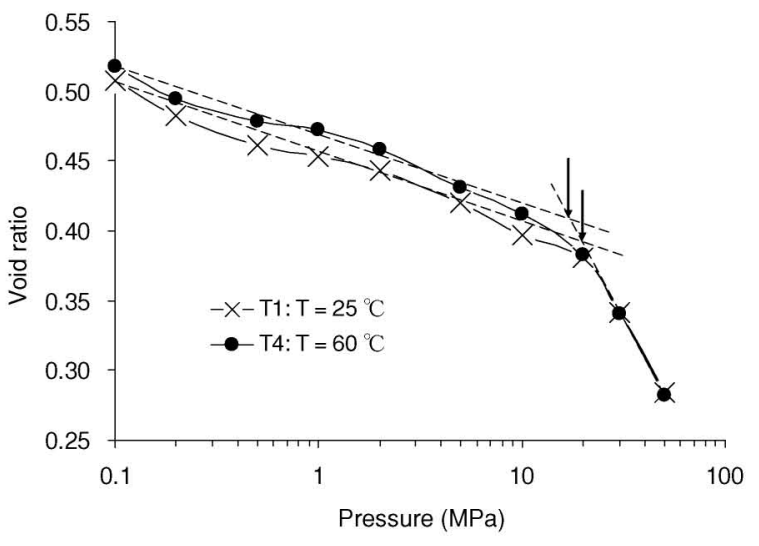

(a) $\mathrm{s}=110 \mathrm{MPa}$

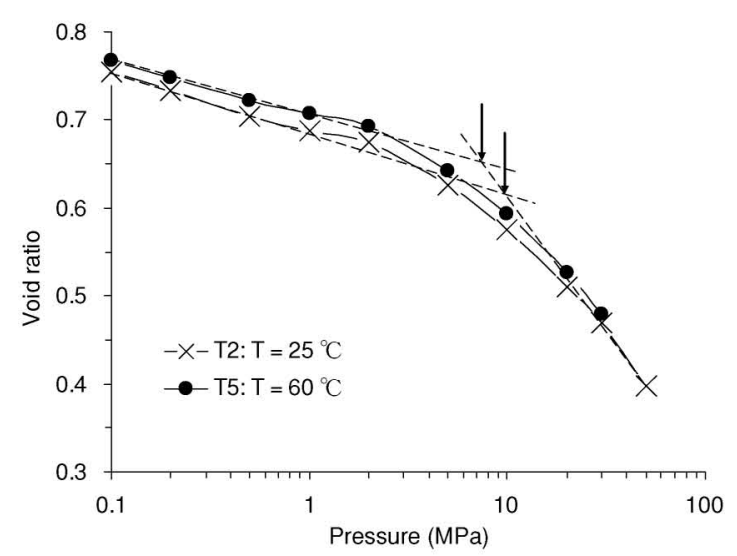

(b) $\mathrm{s}=39 \mathrm{MPa}$

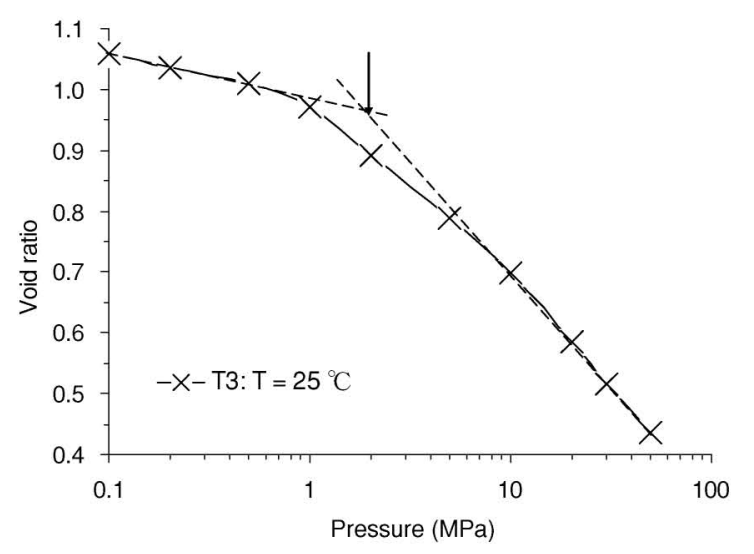

(c) $\mathrm{s}=9 \mathrm{MPa}$

Fig. 7. Results of mechanical loading at constant suction and temperature: tests T1-T6

when the suction is decreased. When the suction is decreased from 110 to $9 \mathrm{MPa}, \kappa$ increases from 0.023 to 0.036 and $\lambda(\mathrm{s})$ increases from 0.120 to 0.165 . Figure 9 shows the yield pressures $p_{0}$ determined from Fig. 7 at various suctions and temperatures. It can be seen that $p_{0}$ decreases from $21 \mathrm{MPa}$ at the initial suction $s=110 \mathrm{MPa}$ to $10 \mathrm{MPa}$ at $s=39 \mathrm{MPa}$ and $2 \mathrm{MPa}$ at $s=9 \mathrm{MPa}$ for the tests at $25^{\circ} \mathrm{C}$. As far as the temperature effect is concerned, at $s=110 \mathrm{MPa}$, heating from $T=25^{\circ} \mathrm{C}$ to $60^{\circ} \mathrm{C}$ decreases $p_{0}$ from 21 to $16 \mathrm{MPa}$. At $s=39 \mathrm{MPa}$ heating 


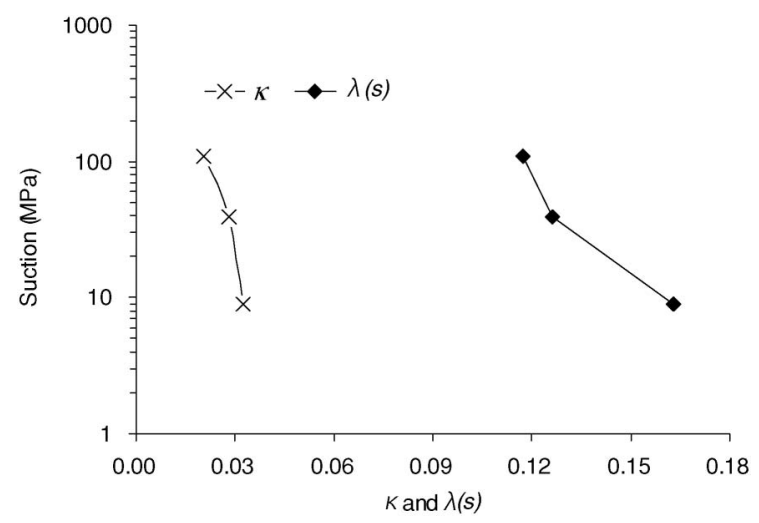

Fig. 8. Compressibility parameters $\kappa$ and $\lambda(s)$ versus suction for tests at $25^{\circ} \mathrm{C}$

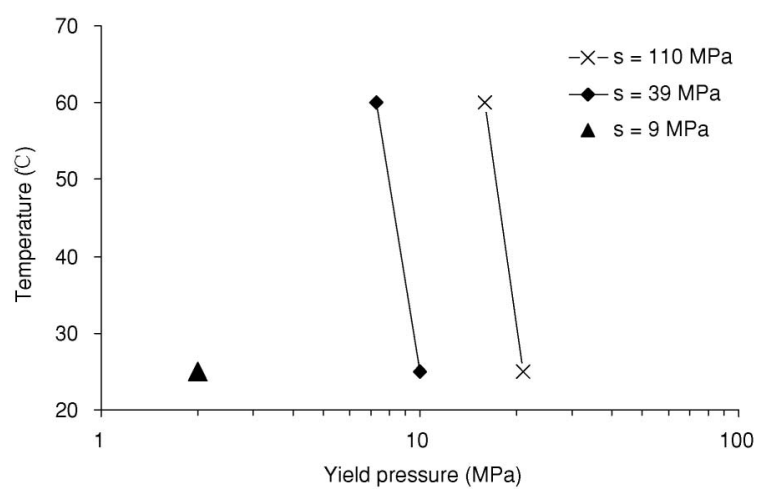

Fig. 9. Yield pressure $p_{0}$ versus temperature

decreases $p_{0}$ from 10 to $7.3 \mathrm{MPa}$.

\section{DISCUSSIONS}

In this section the thermo-mechanical behavior of the GMZ bentonite identified will be discussed by comparing it with that of other reference bentonites (listed in Table 1) which have been studied worldwide.

\section{Mineralogical Properties}

Table 1 shows that the montmorillonite content of the GMZ bentonite is lower than that of the MX80 bentonite and the FEBEX bentonite but it is higher than that of the Kunigel-V1 bentonite. The FoCa bentonite contains $80 \%$ of interstratified smectite/kaolinite. The quartz content of the Kunigel-V1 and the GMZ bentonites is relatively high: $29-38 \%$ and $11.7 \%$ respectively (smaller than $6 \%$ for the others). Good correlations can be established between the montmorillonite content and the CEC values (Fig. 10(a)). Indeed, the higher the montmorillonite content, the larger the CEC; the FEBEX bentonite with the highest montmorillonite content has the largest values of CEC. The FoCa clay with an $80 \%$ interstratified smectite/kaolinite content is not considered in these correlations. As far as the other properties are concerned (Table 2 ), it seems that the specific surface area (S), liquid limit $\left(w_{\mathrm{L}}\right)$ and the plasticity index $\left(I_{\mathrm{p}}\right)$ are not directly related to
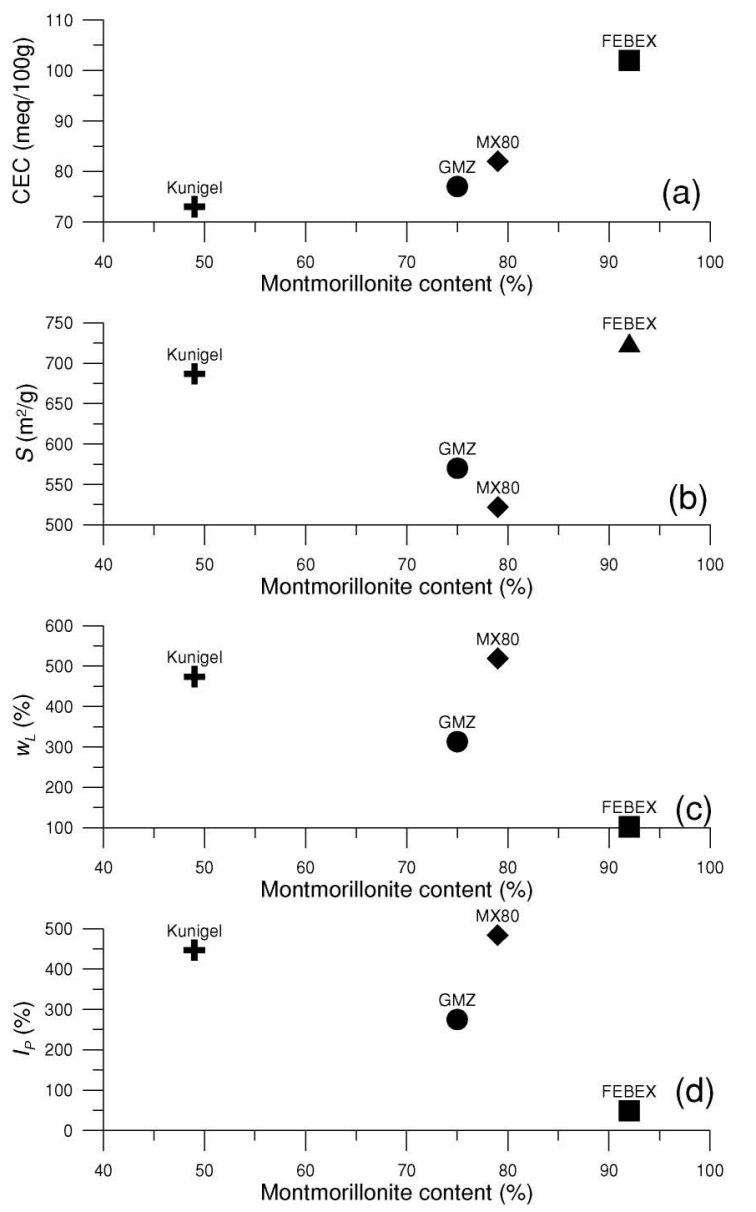

Fig. 10. Correlation between the montmorillonite content with (a) Cations Exchange Capacity, CEC; (b) specific surface area, S; (c) Liquid limit, $w_{\mathrm{L}}$; and (d) Plasticity index, $I_{\mathrm{P}}$

the montmorillonite content (Figs. 10(b), (c) and (d)). For instance, the FEBEX bentonite with the highest montmorillonite content has the smallest values of $w_{\mathrm{L}}$ and $I_{\mathrm{p}}$ while the MX80 bentonite (79\% montmorillonite) has the highest values of $w_{\mathrm{L}}$ and $I_{\mathrm{p}}$. This shows that the montmorillonite content is not the only factor which influences the basic geotechnical properties; other factors, such as the nature of the base cations exchange (see Table 2), must play an important role also.

\section{Thermal Conductivity}

Tang et al. (2008b) studied the thermal conductivity of the compacted MX80, FEBEX and Kunigel bentonites. Tests on the compacted specimens having various dry densities (ranging from 1.45 to $1.85 \mathrm{Mg} / \mathrm{m}^{3}$ ) and water contents show that the thermal conductivity of bentonites is strongly dependent on these two parameters: at the same water content, the higher the density the higher the thermal conductivity, and at the same dry density, the higher the water content, the higher the thermal conductivity. After testing various models for predicting the thermal conductivity, Tang et al. (2008b) found that a unique relationship can be established between the thermal conductivity $K$ and the air-pore volume fraction $V_{\mathrm{a}} /$ $V$ for all these soils, as follows: 


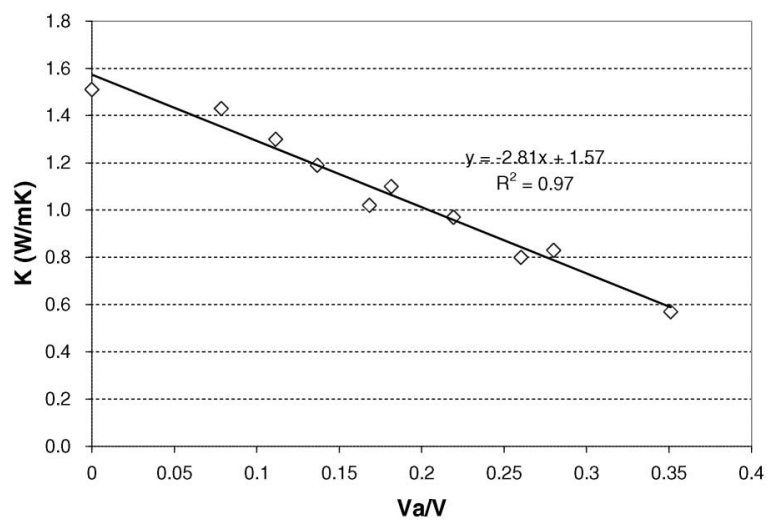

Fig. 11. Variations of thermal conductivity with air-volume fraction for GMZ bentonite (after Wen, 2006)

$$
K=\alpha\left(V_{\mathrm{a}} / V\right)+K_{\mathrm{sat}}
$$

where $\alpha$ is the slope of $K-V_{\mathrm{a}} / V$ plot; $K_{\text {sat }}$ is the thermal conductivity at saturated state which corresponds to the intersection of $K-V_{\text {a }} / V$ plot with the $K$ axis.

Figure 11 shows the $K-V_{\mathrm{a}} / V$ plot for the compacted GMZ bentonite that was drawn using data reported by Wen (2006). It can be seen that there is also a good linear relationship for this bentonite. From Fig. 11 the parameters of Eq. (1) deduced are as follows:

$$
\alpha=-2.81 \mathrm{~W} / \mathrm{mK} \text { and } K_{\text {sat }}=1.57 \mathrm{~W} / \mathrm{mK}
$$

These values are slightly larger than those for other bentonites: FEBEX $\left(\alpha=-2.29 \mathrm{~W} / \mathrm{mK}\right.$ and $K_{\text {sat }}=1.30$ $\mathrm{W} / \mathrm{mK}), \quad \operatorname{MX80}\left(\alpha=-1.79 \mathrm{~W} / \mathrm{mK} \quad\right.$ and $K_{\text {sat }}=1.1$ $\mathrm{W} / \mathrm{mK})$, Kunigel V1 $\left(\alpha=-2.36 \mathrm{~W} / \mathrm{mK}\right.$ and $K_{\mathrm{sat}}=1.39$ $\mathrm{W} / \mathrm{mK})$. Even though relatively larger values of the thermal conductivity at saturated state $\left(K_{\text {sat }}\right)$ for the GMZ and Kunigel-V1 bentonites can be related to their higher quartz contents (see Table 1), it appears that the difference is too small to allow establishing a relevant correlation. Further study is needed to clarify this phenomenon by working on the different bentonites but using the same test protocol and measurement technique.

\section{Swelling Behavior}

Figure 5 shows that for the GMZ bentonite compacted at $1.70 \mathrm{Mg} / \mathrm{m}^{3}$ of dry density (initial suction of 110 $\mathrm{MPa}$ ), wetting to suction at $9 \mathrm{MPa}$ induced a swelling volumetric strain of $32.9 \%$. The volumetric swelling strain of GMZ is plotted together with that of other soils in Fig. 12. A higher value of $50 \%$ was obtained by Tang et al. (2008a) when wetting from a suction of $110 \mathrm{MPa}$ to $9 \mathrm{MPa}$ the MX80 bentonite compacted at $1.78 \mathrm{Mg} / \mathrm{m}^{3}$ of dry density. Delage et al. (1998) showed that wetting the compacted FoCa clay $\left(1.85 \mathrm{Mg} / \mathrm{m}^{3}\right.$ of dry density, initial suction of $110 \mathrm{MPa}$ ) to a suction of $9 \mathrm{MPa}$ induced a volumetric strain of $17 \%$. After ENRESA (2000), wetting the FEBEX bentonite (initially compacted at $1.67 \mathrm{Mg} / \mathrm{m}^{3}$ of dry density) from a suction of $110 \mathrm{MPa}$ to a suction of $9 \mathrm{MPa}$ induced a volumetric strain of $19 \%$. Kanno and Wakamatsu (1993) studied the volume change behavior

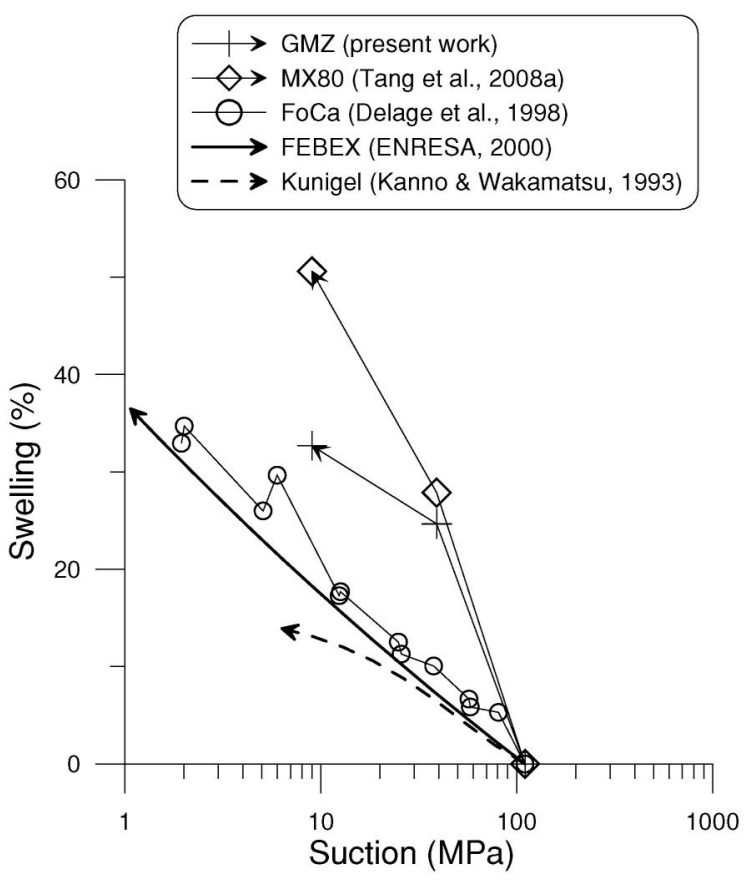

Fig. 12. Swelling of various compacted bentonite from a initial suction of $110 \mathrm{MPa}$

of the compacted Kunigel-V1 (initially compacted at 1.82 $\mathrm{Mg} / \mathrm{m}^{3}$ of dry density) and obtained a volumetric strain of $13 \%$ when wetting from 110 to $9 \mathrm{MPa}$ suction. The comparison shows that the swelling potential of the GMZ and the MX80 is higher than that of FoCa, Kunigel-V1 and FEBEX. This is due to their montmorillonite contents (a higher montmorillonite content gives rise to a higher swelling potential, see Marcial et al., 2002) and the nature of exchangeable basic cations (Na-based bentonites show higher swelling potential than Ca-based bentonites, see Marcial et al., 2002).

\section{Thermal-mechanical Volume Changes}

The coefficient of thermal expansion of the compacted GMZ bentonite deduced from Fig. 6 is $2 \times 10^{-4 \circ} \mathrm{C}^{-1}$ (mean value determined from the thermal expansion curve of tests T4 and T5). Similar values were obtained for the compacted MX80 bentonite (Tang et al., 2008a) and the compacted FEBEX bentonite (Romero et al., 2005). As far as the nature of the volume changes upon heating is concerned, Tang et al. (2008a) observed that heating the compacted MX80 bentonite under 0.1 MPa pressure gave rise to thermal expansion at high suctions (39 and 110 $\mathrm{MPa})$ and to thermal contraction at a lower suction (9 $\mathrm{MPa})$. The same phenomenon was observed in the present work on the GMZ bentonite. This behavior was explained using an elasto-plastic constitutive model proposer by Tang and Cui (2009). The thermal expansion corresponds to an elastic behavior when the heating path remains in the elastic zone while the thermal contraction corresponds to a plastic behavior when the heating path under constant stress and suction touch the yield surface.

The compression curves obtained at controlled suction and temperature (Fig. 7) show an elasto-plastic behavior 
with a clear change in slope. That allowed the determination of the compressibility parameters: $\kappa, \lambda(s)$ and $p_{0}$. Similar observations were made by Tang et al. (2008a) on the MX80 bentonite and by Lloret et al. (2004) on the FEBEX bentonite. The plastic behavior in compacted soil is usually associated with the collapse of macro-pores that can be evidenced by MIP (Mercury Intrusion Porosimetry) test as in the works of Lloret et al. (2003), Tang and Cui (2009), and Tang et al. (2011). However, Cui et al. (2002) performed suction-controlled isotropic compression tests on the highly compacted FoCa clay (compacted initially at $1.85 \mathrm{Mg} / \mathrm{m}^{3}$ of dry density) and observed a reversible volume change behavior in a range of pressures up to $60 \mathrm{MPa}$. The authors explained this by the absence of collapsible macro-pores in this material. That means the volume change behavior of compacted clays can be strongly dependent on the dry density; the higher the dry density (or the lower the volume of macropores) the higher the yield stress. Note that the initial dry densities of bentonite in other studies are lower than in Cui et al. (2000): $1.70 \mathrm{Mg} / \mathrm{m}^{3}$ for FEBEX bentonite in Lloret et al. (2003); $1.78 \mathrm{Mg} / \mathrm{m}^{3}$ for MX80 bentonite in Tang and Cui (2009). In the study of Tang et al. (2011), even at a high dry density of $2.00 \mathrm{Mg} / \mathrm{m}^{3}$, the volume of macro-pores measured by MIP tests is still high. It shows that isotropically compacting GMZ bentonite at $30 \mathrm{MPa}$ pressure (to a dry density of $1.70 \mathrm{Mg} / \mathrm{m}^{3}$ ) can not avoid macro-pores. Further study is necessary to clarify this point.

The effects of suction and temperature on $\kappa$ and $\lambda(s)$ of GMZ bentonite are similar to that of MX80: $\kappa$ and $\lambda(s)$ increase with the decrease of suction but are independent of the temperature changes (between 25 and $60^{\circ} \mathrm{C}$ ). Lloret et al. (2004), however, observed that both the increase of temperature and the decrease of suction induced an increase of $\lambda(s)$ in FEBEX bentonite. Comparing the values of $\lambda(\mathrm{s})$, GMZ bentonite shows the highest values: $\lambda(s)=0.12-0.16$ at $s=9-110 \mathrm{MPa}$ for GMZ bentonite; $\lambda(s)=0.08-0.12$ at $s=9-110 \mathrm{MPa}$ for MX80 bentonite; $\lambda(s)=0.065-0.080$ at $s=8-14 \mathrm{MPa}$ for FEBEX bentonite (from suction-controlled oedometer tests by Lloret et al., 2003).

The effect of temperature on the yield stress $p_{0}$ of GMZ bentonite and MX80 bentonite (see Tang et al. 2008a) is similar; only a slight decrease of $p_{0}$ was observed for high suction values $(s=110$ and $39 \mathrm{MPa})$. In contrast, for FEBEX bentonite, at $s=120 \mathrm{MPa}$, Lloret et al. (2004) showed that $p_{0}$ decreased drastically from $20 \mathrm{MPa}$ (at $20^{\circ} \mathrm{C}$ ) to $3 \mathrm{MPa}\left(\right.$ at $\left.50^{\circ} \mathrm{C}\right)$.

In order to compare the effect of suction decrease on the yield stress, the results of three bentonites (GMZ, MX80 and FEBEX) are plotted together in Fig. 13. At high suctions $(s=110-127 \mathrm{MPa})$, the yield stresses of the three soils are close to $20 \mathrm{MPa}$. Upon wetting, the yield stress decreases in similar pattern for GMZ bentonite and FEBEX bentonite but at a lower rate than MX80 bentonite: at $s=9 \mathrm{MPa}, p_{0}$ of GMZ and FEBEX bentonites decreases to $2 \mathrm{MPa}$ while that of MX80 is much lower $(0.38 \mathrm{MPa})$.

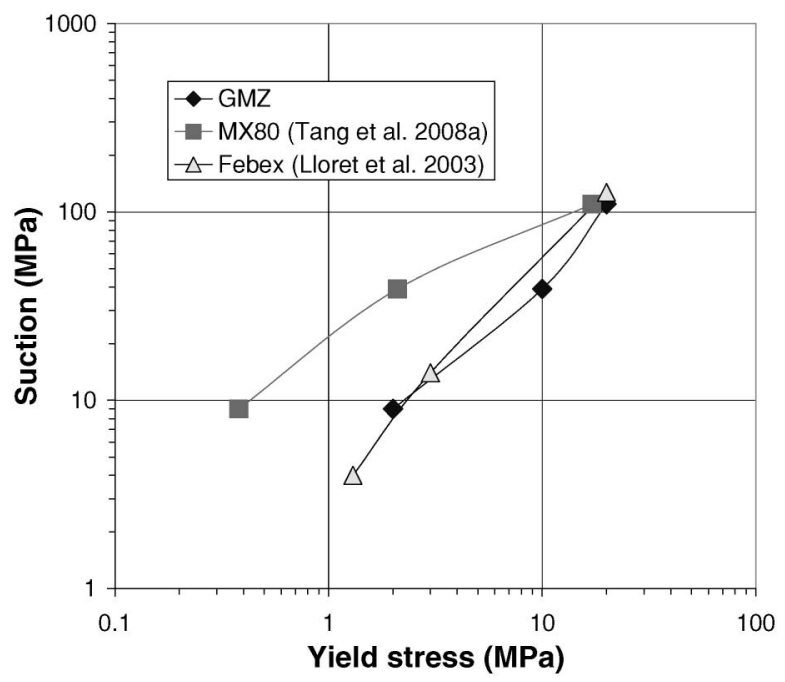

Fig. 13. Relationship between yield stress and the applied suction for various bentonites

\section{CONCLUSIONS}

The thermo-mechanical behavior of GMZ bentonite, which has been selected as a possible material for the engineered barriers in the high-level radioactive waste disposals in China, was experimentally investigated. The results obtained were compared with other bentonites which have been widely investigated as reference materials in the projects carried out in other countries (MX80, FEBEX, FoCa, and Kunigel-V1). The following conclusions can be drawn from the present study:

i) The montmorillonite content of GMZ bentonite is lower than that of MX80 bentonite and FEBEX bentonite but it is higher than that of Kunigel-V1 bentonite. That explains the large values of its cations exchange capacity (CEC) and specific surface area S. In general, good correlations can be established between the montmorillonite content and the CEC values or the specific surface area $S$ (Table 2). Nevertheless, no direct correlation can be made between the montmorillonite content and the basic geotechnical properties; other factors, such as the nature of base exchangeable cations, also appear to have a significant influence.

ii) The same observation has been made in terms of swelling potential. In general, the higher the montmorillonite content, the higher the swelling potential. However, a Ca-based bentonite generally shows lower swelling potential than a Na-based bentonite. For GMZ bentonite it was observed that wetting (suction decreased from 110 to $9 \mathrm{MPa}$ ) induced a swelling volumetric strain of $30 \%$. That is lower than MX80 (50\%) and higher than that of other bentonites (less than 20\%).

iii) The quartz content of GMZ bentonite is relatively high $(11.7 \%)$ just behind Kunigel-V1 bentonite (29-38\%). This could explain their relatively large values of thermal conductivity. Note that compared 
to the values for other bentonites, the difference is too small to allow for a relevant correlation to be drawn between their thermal conductivity and the quartz content.

iv) The coefficient of thermal expansion of the compacted GMZ bentonite is $2.10^{-4 \circ} \mathrm{C}^{-1}$, that is similar to the values obtained for the compacted MX80 bentonite (Tang et al., 2008a) and the compacted FEBEX bentonite (Romero et al., 2005). As the compacted MX 80 bentonite, the GMZ bentonite also showed a thermal expansion upon heating at high suctions (39 and $110 \mathrm{MPa}$ ) and a thermal contraction at lower suction (9 $\mathrm{MPa})$.

v) The effect of suction and temperature on $\kappa$ and $\lambda(s)$ of GMZ bentonite is similar to MX80: $\kappa$ and $\lambda(s)$ increase with decreasing suction but are independent of the temperature changes. Compared to other bentonites, GMZ bentonite has the highest values of $\lambda(s): 0.12-0.16$ at $s=9-110 \mathrm{MPa}$.

vi) The effect of temperature on the yield stress $p_{0}$ of the GMZ bentonite has been found to be insignificant. A similar observation was made for MX80 bentonite by Tang et al. (2008a). In contrast, a significant suction effect was identified. As is also the case for MX80 bentonite and FEBEX bentonite, the yield stress $p_{0}$ of the GMZ bentonite decreased significantly, at a rate similar to that of FEBEX bentonite but lower than that of MX80 bentonite.

\section{ACKNOWLEDGEMENTS}

The authors are grateful to the National Natural Science Foundation of China (No 40728003 and No 41030748), Kwang-Hua Fund for College of Civil Engineering at Tongji University, and Program for Changjiang Scholars and Innovative Research Team in University (PCSIRT, IRT1029).

\section{REFERENCES}

1) Alonso, E. E., Gens, A. and Josa, A. (1990): A constitutive model for partially saturated soils, Géotechnique, 40(3), 405-430.

2) Chen, B., Qian, L. X., Ye, W. M., Cui, Y. J. and Wang, J. (2006): Soil-water characteristic curves of Gaomiaozi bentonite, Chinese Journal of Rock Mechanics and Engineering, 25(4), 788-793.

3) Cui, Y. J., Sultan, N. and Delage, P. (2000): A thermo-mechanical model for saturated clays, Can. Geotech. J., 37(3), 607-620.

4) Cui, Y. J., Yahia-Aissa, M. and Delage, P. (2002): A model for the volume change behaviour of heavily compacted swelling clays, Engineering Geology, 64(2), 233-250.

5) Cui, Y. J., Tang, A. M., Loiseau, C. and Delage, P. (2008): Determining the unsaturated hydraulic conductivity of a compacted bentonite-sand mixture under confined and free-swell conditions, Physics and Chemistry of the Earth, 33(S1), S462-S471.

6) Delage, P., Howat, M. D. and Cui, Y. J. (1998): The relationship between suction and swelling properties in a heavily compacted unsaturated clay, Engineering Geology, 50(1), 31-48.

7) ENRESA (2000): Full-scale engineered barriers experiment for a deep geological repository for high-level waste in crystalline host rock. Final Report, Technical Publication ENRESA 01/2000, Madrid, 354

8) Guillot, X., Al-Mukhtar, M., Bergaya, F. and Fleureau, J. M.
(2002): Estimation de la porosité dans un matériau argileux, C.R. Geoscience, 334, 105-109.

9) JNC (2000): H12 Project to establish technical basis for HLW disposal in Japan, Supporting report 3, Safety assessment of the geological disposal system, JNC Tech. Rep., JNC TN1410 2000-004.

10) Johannesson, L. E., Börgesson, L., Goudarzi, R., Sandén, T., Gunnarsson, D. and Svemar, C. (2007): Prototype repository: A full scale experiment at Äspö HRL, Physics and Chemistry of the Earth, 32, 58-76.

11) Kanno, T. and Wakamatsu, H. (1993): Moisture adsorption and volume change of partially saturated bentonite buffer materials. Materials Research Society Symposia Proceedings, 294: 425-430.

12) Komine, H. (2004): Simplified evaluation on hydraulic conductivities of sand-bentonite mixture backfill, Applied Clay Science, 26(1-4), 13-19.

13) Lloret, A., Villar, M. V., Sanchez, M., Gens, A., Pintado, X. and Alonso, E. E. (2003): Mechanical behaviour of heavily compacted bentonite under high suction changes, Géotechnique, 53(1), 27-40.

14) Lloret, A., Romero, E. and Villar, M. V. (2004): FEBEX II Project, Final report on thermo-hydro-mechanical laboratory tests, ENRESA Technical Publication 10/2004.

15) Lloret, A. and Villar, M. V. (2007): Advances on the knowledge of the thermo-hydro-mechanical behaviour of heavily compacted "FEBEX" bentonite, Physics and Chemistry of the Earth, 32, 701-715.

16) Marcial, D., Delage, P. and Cui, Y. J. (2002): On the high stress compression of bentonites, Canadian Geotechnical Journal, 39, $812-820$.

17) Martino, J. B., Dixon, D. A., Kozak, E. T., Gascoyne, M., Vignal, B., Sugita, Y., Fujita, T. and Masumoto, K. (2007): The tunnel sealing experiment: An international study of full-scale seals, Physics and Chemistry of the Earth, 32, 93-107.

18) Montes-H., G., Duplay, J. Martinez, L. and Mendoza, C. (2003): Swelling-shrinkage kinetics of MX80 bentonite, Applied Clay Science, 22, 279-293.

19) Romero, E., Villar, M. V. and Lloret, A. (2005): Thermo-hydromechanical behaviour of heavily overconsolidated clays, Engineering Geology, 81, 255-268.

20) Sugita, Y., Fujita, T., Takahashi, Y., Kawakami, S., Umeki, H., Yui, M., Uragami, M. and Kitayama, K. (2007): The Japanese approach to developing clay-based repository concepts-An example of design studies for the assessment of sealing strategies, Physics and Chemistry of the Earth, 32, 32-41.

21) Tang, A. M. and Cui, Y. J. (2005): Controlling suction by the vapour equilibrium technique at different temperatures and its application in determining the water retention properties of MX80 clay, Canadian Geotechnical Journal, 42(1), 287-296.

22) Tang, A. M., Cui, Y. J. and Barnel, N. (2007): A new isotropic cell for studying the thermo-mechanical behavior of unsaturated expansive soil, Geotechnical Testing Journal, 30(5), 341-348.

23) Tang, A. M., Cui, Y. J. and Barnel. N. (2008a): Thermo-mechanical behaviour of a compacted swelling clay, Géotechnique, 58(1), 45-54.

24) Tang, A. M., Cui, Y. J. and Le, T. T. (2008b): A study on the thermal conductivity of compacted bentonites, Applied Clay Science, 41, 181-189.

25) Tang, A. M. and Cui, Y. J. (2009): Modelling the thermo-mechanical behaviour of compacted expansive clays, Géotechnique, 59(3), 185-195.

26) Tang, C. S., Tang, A. M., Cui, Y. J., Delage, P., Barnichon, J. D. and Shi, B. (2011): A study of the hydro-mechanical behaviour of compacted crushed argillite, Engineering Geology, 118(3-4), 93-103.

27) Van Geet, M., Volckaert, G., Bastiaens, W., Maes, N., Weetjens, E., Sillen, X., Vallejan B. and Gens, A. (2007): Efficiency of a borehole seal by means of pre-compacted bentonite blocks, Physics and Chemistry of the Earth, 32, 123-134.

28) Wang, J., Sui, R., Chen, W., Guo, Y. H., Jin, Y. X., Wen, Z. J. and Liu, Y. M. (2006): Deep geological disposal of high-level radioactive wastes in China, Chinese Journal of Rock Mechanics 
and Engineering, 25(4), 649-658.

29) Wen, Z. J. (2006): Physical property of China's buffer material for high-level radioactive waste repositories, Chinese Journal of Rock Mechanics and Engineering, 25(4), 794-800.
30) Ye, W. M., Cui, Y. J., Qian, L. X. and Chen, B. (2009): An experimental study of the water transfer through compacted GMZ bentonite, Engineering Geology, 108, 169-176. 